\title{
The Existence of Trade Union on the Implementation of Outsourcing Worker Policy in the Rights of Labour: Case from Indonesia
}

\author{
Bachrul Amiq ${ }^{1}$, Liosten Rianna Roosida Ully Tampuboon ${ }^{2, ~ *, ~ E d y ~ W i d a y a t ~}{ }^{3}$ \\ ${ }^{1}$ Faculty of Law, Dr Soetomo University, Surabaya, Indonesia \\ ${ }^{2}$ Faculty of Economic and Business, Dr. Soetomo University, Surabaya, Indonesia \\ ${ }^{3}$ Faculty of Teacher Training and Education, Dr, Soetomo University Surabaya, Surabaya, Indonesia
}

Email address:

liostenully@yahoo.com (L. R. R. U. Tampuboon)

${ }^{*}$ Corresponding author

\section{To cite this article:}

Bachrul Amiq, Liosten Rianna Roosida Ully Tampuboon, Edy Widayat. The Existence of Trade Union on the Implementation of Outsourcing Worker Policy in the Rights of Labour: Case from Indonesia. Journal of Public Policy and Administration. Vol. 5, No. 1, 2021 , pp. $24-29$. doi: $10.11648 /$ j.jppa.20210501.14

Received: December 25, 2020; Accepted: January 7, 2021; Published: April 1, 2021

\begin{abstract}
The form of deviation in the application of outsourcing policy and the system of work agreement for a certain time include: (1) the company has not classified the core and noncore business; (2) outsourcing workers and contract workers are not included in the worker's social security program, (3) outsourcing workers have no job security, career guarantees, and continuity of work; and (4) the tendency of job hire companies and employment service providers to pay wages lower than the regency minimum wage. Irregularities in the implementation of outsourcing policies led to conflicts of interest, disharmonious organizational communication, and mistrust of workers towards management. This problem triggerred demonstrations and strikes by workers and trade unions. On the other hand, supervision and guidance from the local manpower office had not been effective. Therefore, the role and existence of trade unions were necessary to fight for workers 'rights and legal certainty to protect workers' rights. The results of this study revealed the existence of trade unions through mass demonstrations nationally and to reject the outsourcing system can pressure the East Java Governor to conduct a moratorium on outsourcing and the Indonesian government to design Omnibuslaw outsourcing. On the one hand, Omnibuslaw aims to facilitate the outsourcing system and on the other hand provides a favorable compensation for workers in the form of a pension guarantee. Previous research showed that trade union advocacy on the implementation of the Law of the Republic of Indonesia No. 21 of 2000 produced a model of trade union advocacy and the role of trade unions in determining district minimum wages. This research was a downstreaming from previous research conducted at employer companies, union outsourcing companies, and labour agencies in East Java.
\end{abstract}

Keywords: Trade Unions, Outsourching, Workers Rights

\section{Introduction}

Law of the Republic of Indonesia Number 13 of 2003 concerning Employment and Trade Unions states that the function of trade unions is to be a good mediator between companies and workers or labourers and to fight for the welfare of workers or labourers and their families. Implementation of the function of trade unions is as social control of the implementation of labour laws and regulations carried out by related parties, namely companies and workers or labourers. The issue of employment in Indonesia is very complex, especially the problem of outsourcing. Until now, in Indonesia, there is no basic standard model of proper outsourcing implementation.

Increasing competition in international and national markets and the high annual minimum wage increases of districts make companies have to carry out efficiency in all fields and transfer part of the work to the second party to provide workers or labourers who carry out work received from employer companies; so the employer company is more 
focused on company development and marketing expansion. Outsourcing is an effort of the company by using assistance from other companies to do work that supports the business and get maximum profit [8].

Outsourcing labour has long been developing in Indonesia, especially in the form of contracting jobs in the mining sector Then, outsourcing develops in other sectors, such as industry, trade, hospitality, cleaning services, security, and hospitals [4]. This development resulted in the issuance of the Decree of the Minister of Trade of the Republic of Indonesia Number 264 / KP / 1989 concerning Management of Subcontracting in the Nusantara Bonded Zone [11]. In general, the rate outsourcing application in the world in the globalisation era in industry 4.0 has increased sharply. Therefore, BARTKUS and JUREVICIUS refer to the industrial era 4.0 as THE AGE OF OUTSOURCING [6].

The problem of outsourcing is very complicated. On the one hand, the outsourcing system benefits the company. However, on the other hand, outsourcing is considered detrimental to workers because the outsourcing system in Indonesia does not provide future insurance. The outsourcing work agreement uses a specific time employment agreement. After expiring, the employment contract can be extended once. After that, the work period cannot be extended anymore. Thus, in an outsourcing system, there is no tenure, no future insurance, no employment insurance, and no legal certainty. Trade unions as social control and workers' or workers' organisations fighting for the welfare of workers and their families consider that the outsourcing system is very detrimental to workers or workers who have no bright future. The outsourcing system in Indonesia is implicitly regulated in Law of the Republic of Indonesia Number 13 of 2003 concerning Manpower Article 64, Article 65 and Article 66. The regulation states that the company can delegate part of the work to other companies through a written agreement on the employment contract or the provision of workers' services or labourers made. Unions consider Law Number 13 of 2003 which does not state a binding relationship between an outsourced worker and an outsourcing user company is an indication of an unfavourable legal relationship between the outsourcing worker and the outsourcing user company. Regulation of the Minister of Manpower and Transmigration of the Republic of Indonesia Number 19 of 2012 Article 14 and Article 17 states that outsourced workers are only bound to work relationships with employment contracting companies. This phenomenon is a form of obscurity or vagueness of norms that need to be reviewed in terms of legal certainty in terms of implementing outsourcing systems for harmonious industrial relations.

Law of the Republic of Indonesia Number 13 of 2003 concerning Manpower states that the type of work that can be transferred by the employer to the provider of labour or labourers who receives work is work that is not the primary job (core business) but supporting work. However, in reality, the outsourcing worker does the main work, and the outsourcing company does not register a specific time work agreement between outsourcing companies and workers or labourers to the local labour service. The union suspected that the outsourcing company was intentionally not registering the specified time employment agreement for fear that the labour agency did not approve the outsourcing agreement with the employer because the outsourcing worker was working on core business. Most companies providing workers or labourers employ workers continuously. This condition caused a strong reaction from the union. They want to fight for the rights of workers or labourers under labour regulations stipulated in the Law of the Republic of Indonesia Number 13 of 2003 concerning Labour article 64, article 65 and article 66 and Regulation of the Minister of Manpower and Transmigration Number 19 of 2012 article 14 and article 17. Trade unions hold massive national protests every Labour Day so that the outsourcing system is abolished in Indonesia. The role of trade unions as good mediators between companies and workers or labourers cannot be carried out correctly. Trade unions actively advocate for workers or labourers about outsourcing regulations, outsourcing system weaknesses, and outsourcing deviations. Then, there were protests of workers or workers together with trade unions or labour organisations. The wave of protests that rejected the outsourcing system in Indonesia has not stopped since the Law of the Republic of Indonesia Number 13 of 2003 concerning Labour was established. As a result, the situation is increasingly not conducive, and industrial relations are not harmonious, many companies relocate to other countries, more and more unilateral termination of employment, and more unemployment and crime increases. Deviations in the implementation of the outsourcing system affect the performance of workers or labourers, low work motivation, and high burnout rates [2]; [12].

The problem faced is how the existence of trade unions in upholding the rules of the Law of the Republic of Indonesia Number 13 of 2003 concerning Labour article 64, articles 65 and 66 and Regulation of the Minister of Manpower and Transmigration of the Republic of Indonesia Number 19 of 2012 Article 14 and Article 17 so that the rights workers or labourers are protected and obtain legal certainty to create harmonious industrial relations.

\section{Methods}

This research was phenomenological research using descriptive qualitative method. The purpose of this study was to analyse the existence of trade unions as a social control over the implementation of outsourcing following Law No. 13 of 2003 article 64, article 65, and article 66 and regulation of the Minister of Manpower and Transmigration Number 19 of 2012 article 14 and article 17 for creating harmonious industrial relations [5]. The objects of this research were the employer companies, labour service providers, job contracting companies, trade unions, Indonesian employers' associations, and workers. Data was collected through indepth interview triangulation [9], expert surveys, and reputable international journals [3]. Data were analysed 
descriptively qualitatively and empirically juridical to support the originality of the study.

\section{Result}

This study aimed to determine and analyse the existence of trade unions in addressing the implementation of outsourcing in Indonesia, especially in the city of Surabaya. The results of this research resulted in 5 forms of union that exists in the implementation of outsourcing, namely:

1. Reject Outsourcing System

The legal basis governing the implementation of the outsourcing system, namely:

a. The legal basis governing the implementation of the outsourcing system, namely:

b. Law Number 13 of 2003 concerning Manpower, specifically article 64, article 65 and article 66.

c. Regulation of the Minister of Manpower and Transmigration of the Republic of Indonesia Number 19 of 2012 concerning the conditions for the partial surrender of work to other companies.

d. Decree of the Minister of Manpower and Transmigration of the Republic of Indonesia Number: KEP 220 / MEN / X / 2004 Regarding the Conditions for Submitting Part of Work Implementation to Other Companies.

e. Decree of the Minister of Manpower and Transmigration of the Republic of Indonesia Number: KEP 10 / MEN / V / 2004 concerning Provisions for Implementing Specific Time Work Agreement.

f. Circular of the Minister of Manpower and Transmigration of the Republic of Indonesia Number: SE. 04 / MEN / VIII / 2013 Concerning Guidelines for Implementing the Regulations of the Minister of Manpower and Transmigration of the Republic of Indonesia, Regulation of the Minister of Manpower and Transmigration of the Republic of Indonesia Number 19 of 2012 Regarding the Conditions of Partial Submission Work implementation to other companies.

There are many deviations in the implementation of outsourcing in Indonesia, especially in the city of Surabaya, because they do not follow the rules and regulations. The Chairperson of the Surabaya City Indonesia Trade Union Branch Representative Council, Dendi, stated that:

"At first, the reason companies used outsourcing was to reduce the burden on the company in the future, namely giving severance pay to workers when retiring. Companies usually use two methods, namely contract and outsourcing systems. In a contract system, the chartering of work is carried out according to a specific time work agreement. Meanwhile, in the outsourcing system, the company delegates part of the work to other companies through companies providing workers' services. However, job outsourcing and outsourcing are the same."

Law of the Republic of Indonesia, Number 13 of 2003 concerning Manpower Article 65 paragraph (1), states:

"The delegation of part of the work carried out to other companies is carried out through a written agreement chartering the work made."

Several conditions must be met in an outsourcing system. Regulation of the Minister of Manpower and Transmigration of the Republic of Indonesia Number 19 of 2012 concerning Terms of Submission of Partial Work Implementation to Other Companies Article 3 paragraph (c) states:

"It is a supporting activity for the company as a whole, meaning that the activity is an activity that supports and facilitates the implementation of main activities in accordance with the workflow process of the work implementation determined by business sector associations formed in accordance with statutory regulations."

Nevertheless, in reality, many employer companies transfer the implementation of main work (core business) to the provider of workers or labourers. Marjuki, SH., Deputy Chairperson of the Board of Directors of the All-Indonesian Trade Union Branch of Surabaya, claimed that:

"The case of irregularities in the outsourcing system at the Unilever Company that I filed with the Transmigration Manpower Office of the Republic of Indonesia, East Java Province, occurred. The work that is transferred by the Unilever company to an outsourcing company is the main work, not supporting work."

He asserted further:

"The flow of the work implementation process determined by the Business Sector Association does not yet exist. This business sector association is established only through a notarial deed. Employers and labour providers can utilise this. It is easy to get an appointment from a business sector association because companies can negotiate with business sector associations. This is the weakness of the conditions for the partial transfer of work to other companies."

Similarly, Dendi stated:

"Most of the companies providing Manpower Services do not include their workers as participants in the Social Security Organizing Agency. Even if registered, only as participants accident insurance and life insurance. For retirement benefits, workers or labourers are not included. If it is like this, it means that workers with outsourcing systems do not have retirement benefits, workers are disadvantaged. Salary payments are also many below the district minimum wage. There is even a difference between the salaries of permanent workers and the salaries of contract workers."

Irregularities in the implementation of the outsourcing system include: (1) work that is transferred to a labour service provider company is the core business; (2) the type of supporting work submitted to the contracting recipient company is not reported by the employer to the regency/city manpower service; the recipient company does not register (3) certain time work agreements to the district/city labour agency; (4) workers or labourers are not included as participants in the Social Security Organizing Body, so there is no retirement insurance; (5) there is wage or salary discrimination between permanent workers and workers or contract labourers or outsourcing systems; (5) the existence 
of employer companies actions towards intimidation of workers or labourers who are members of trade unions. Such conditions cause industrial relations are not harmonious.

There is resistance from workers and trade unions against the employer company as well as against the job contracting company which has violated Law Number 13 of 2003 Concerning Manpower; Regulation of the Minister of Manpower and Transmigration of the Republic of Indonesia Number 19 of 2012 Regarding the Conditions for Submission of Partial Work Implementation to Other Companies. This phenomenon has an impact on Trade Unions and all its members who declare their extensions by rejecting the outsourcing work system and demanding changes to the outsourcing system that provides workers with retirement insurance.

\section{Fighting for Workers' Right}

Complaints regarding the deviation of the outsourcing system at PT Unilever Indonesia and companies receiving contracting jobs namely the Unilever Indonesia Employees Cooperative, PT DHL, PT Valdo Sumber Mandiri and PT Poly Arrad to the East Java Manpower and Transmigration Office through the Civil Servant Supervisors are one form of the existence of Trade Unions in fighting for the normative rights of workers or labourers and improving the welfare of workers or labourers and their families. Nuryanto, chairman of the East Java National Workers' Union stated that:

"There are many normative rights for workers or labourers of the outsourcing system that are not paid by the company, for example, the Social Security Organizing Agency is not included, especially the Old Age Insurance; overtime is counted as dead over time, meaning that overtime per hour is the same amount; no holiday allowance; labour costs are far from the Regency minimum wage, and Specific Time Work Agreements carried out continuously."

Suwono, chairman of Bank Niaga Trade Union Work Unit and Tunjungan Crystal Hotel, stated:

"My fellow Tunjungan Crystal Hotel workers and I struggled together to demand that the company be appointed as permanent employees. Several employees have worked for more than ten years but are still being contracted by the company Tunjungan Crystal Hotel. At that time, my friends and I asked for help from Mr Basuki as Chairman of the Board of Directors of the Trade Union Trade Unions and the Bank of Surabaya to accompany us to dispute with the Surabaya City Manpower Office. Bipartite negotiations occurred many times, went on strike several times, then mediated in terms of employment conditions, until the suggestion from the Surabaya City Manpower Office, that the contracted employees were appointed by the Tunjungan Crystal Hotel company to become permanent employees; from a specific time work agreement to an indefinite time work agreement."

A union can assist workers or their members when workers feel disadvantaged by the employer or employer accepting the job, even if the union is not a lawyer. This is in line with the Law of the Republic of Indonesia Number 13 of 2003 Article 143 paragraph (1) and the Law of the Republic of
Indonesia Number 21 of 2000 concerning Trade Unions / Labour Unions article 4 paragraph (1) and Article 25 paragraph (b). The Law of the Republic of Indonesia Number 13 of 2003 concerning Manpower article 143 paragraph (1) states:

"Anyone cannot prevent workers/labourers and trade/labour unions from using the right to strike legally, orderly and peacefully."

Law of the Republic of Indonesia, Number 13 of 2003 concerning Manpower and Trade Unions article 4 paragraph (1), states:

"Trade unions/labour unions, federations and confederations of trade unions/labour unions aim to provide protection, defence of rights and interests and to improve decent welfare for workers/labourers and their families."

Article 25 paragraph (b) states:

"Representing workers/labourers in resolving industrial disputes."

The existence of trade unions/labour unions is very influential on the success of the settlement of rights disputes and conflicts of interests. Most of the education level of workers/labourers in Indonesia, especially in the city of Surabaya, is still low. Most only graduated from elementary school and junior high school. Understanding of labour legislation is also still very little or low, so workers or labourers need to get protection and assistance, especially when workers or labourers with outsourcing systems are disadvantaged by the employer receiving a job contract [10]

\section{Moratorium of Labour Service Providers}

Because there are so many irregularities in the implementation of the outsourcing work system, the union conducts mass demonstrations nationally every year. As a result, the labour situation in Indonesia, especially the city of Surabaya, is increasingly not conducive. All trade unions in East Java exerted enormous pressure with mass demonstrations in front of the East Java Governor's Office. Due to the intense pressure and demand to reject the outsourcing system, the Governor of East Java issued a moratorium. The union believes that the Minister of Manpower and Transmigration's regulations are weak and have no legal force. Marjuki, SH., Deputy Chairperson of the Surabaya City of All Indonesian Trade Union Branch stated:

"The product of the supervisors is a special note relating to complaints of deviations from other laws/regulations. So, when the company does not want to carry out the official memorandum, the aggrieved party, in this case, the complainant/worker, can file a determination/ratification in the District Court. Meanwhile, the District Court, in terms of employment, is represented by a Career judge who is in the Industrial Relations Court. Therefore, if this special memorandum can be implemented, the District Court can determine it. However, until now there has been no implementation instructions for the legal actions of the District Court for the stipulation. If you wish, according to the Law of the Republic of Indonesia Number 2 of 2004 concerning Settlement of Industrial Relations Disputes, it 
must first be disputed through bipartite. Thus, recommendations arose as initial capital for Industrial Relations Dispute Settlement. So, it can be concluded when there is a Special Note, and it is difficult to ask for the determination of the District Court because there are no implementation instructions and technical instructions from the Supreme Court. Thus, Minister of Manpower and Transmigration Regulation No. 19 of 2012, there is a legal or barren vacuum."

From this situation, the government needs to be present in the law and provide amendments to the changes in the legislation related to the outsourcing system so that it has a strong legal force. This condition motivated the union to show the existence of the union urging the Governor of East Java to conduct an outsourcing moratorium in 2015.

4. As a Social Control to Criticise Government Policies That Do Not Defend Workers

Suwono, head of the management unit of the Trade Trade Union and the Tunjungan Crystal Hotel Company Bank, stated:

"There is a legal vacuum in the Regulation of the Minister of Manpower and Transmigration of the Republic of Indonesia Number 19 of 2012. Trade unions, as social controls criticise these regulations so that workers are not disadvantaged. When a special inspection note is issued by the East Java Manpower and Transmigration Office, a District Court cannot be determined because there are no implementation instructions or technical instructions."

Dendy, chairman of the Board of Directors of the Surabaya Branch of All Indonesia Trade Unions, claimed:

"Trade unions and workers are waiting for Omnibus Law outsourcing. The government is trying to facilitate the implementation of outsourcing by providing rules that have legal force for workers and providing a pension for workers or labourers. If this is the case, trade unions and workers or labourers in Indonesia will support and implement the regulations on the outsourcing work system as well as possible. Now unions and workers are waiting for Omnibus Law outsourcing."

Leli Siregar, SH., MH., Regional Coordinator for Civil Servants Supervisors of the East Java Manpower and Transmigration Office stated:

"There is indeed a moratorium on outsourcing in East Java in response to the demonstration by the Trade Union. However, no registration can be done online nationwide. Means, this provides an opportunity for labour service providers to register their companies. Regional regulations cannot defeat the regulations above that apply nationally. Therefore, omnibus law outsourcing is needed to solve problems in the outsourcing system."

On the other hand, the existence of unions is needed to oversee so that the omnibus law outsourcing will be better, and there is a definite legal guarantee. Research into the existence of trade unions in the implementation of outsourcing policies to fight for workers' rights is in line with Baatartogtokh research on the implementation of outsourcing in Canadian mining companies. He found that the outsourcing system only did work that was not directly related to the production process. The purpose of mining companies in Canada to use an outsourcing system is to do supporting work to improve efficiency and the need for skills and knowledge that the company lacks. The existence of trade unions to educate and assist workers can motivate workers or labourers to work with discipline and create harmonious industrial relations [1].

The results of this study are in line with research conducted by Rahim in Malaysia who found that in the outsourcing system in Malaysia, employment relationships are outlined in contractual agreements between employer companies in Malaysia and labour supply companies from various countries namely Bangladesh, Indonesia, Thailand, India, China, Sri Lanka, Pakistan and Vietnam. Thus, there is no legally binding work relationship between employer companies in Malaysia and workers who do the work provided [10].

\section{Conclusion}

Strengthening the Government's Role includes two things. First, supervision that ensures that the implementation of outsourcing policy is in accordance with the provisions of the Law of the Republic of Indonesia Number 13 of 2003 and its derivative regulations. Second, enforcement of violations of outsourcing policies is carried out firmly and fairly following applicable regulations. However, the most essential role of government is prevention through coaching, character education and training.

Strengthening the existence of trade unions includes three things. First, fighting for the rights of workers' normative rights according to the Law of the Republic of Indonesia Number 13 of 2003 implemented by companies providing labour services correctly and adequately. Second, reject the outsourcing system that does not obey the regulation of the Minister of Manpower and Transmigration No. 19 of 2012. Third, reject all forms of legal products that are not in favour of workers or labourers.

\section{References}

[1] Baatartogtokh, B., Dunbar, W. S., \& van Zyl, D. (2018). The state of outsourcing in the Canadian mining industry. Resources Policy, 59 (March), 184-191. https://doi.org/10.1016/j.resourpol.2018.06.014.

[2] Bass, B. M., Avolio, B. J., Jung, D. I., \& Berson, Y. (2003). Predicting unit performance by assessing transformational and transactional leadership. Journal of Applied Psychology, 88 (2), 207-218. https://doi.org/10.1037/0021-9010.88.2.207.

[3] Farooq, M. B. (2015). Qualitative telephone interviews: Strategies for success. 18th Annual Waikato Management School Student Research Conference, 1-30.

[4] Kakabadse, N., \& Kakabadse, A. (2006). Journal of Management Development. In Journal of Management Development (Vol. 25, Issue 8). https://doi.org/10.1108/jmd.2006.02625haa.001. 
[5] Kelliher, F. (2005). Interpretivism and the pursuit of research legitimisation: An integrated approach to single case design. Electronic Journal of Business Research Methods, 3 (2), 123132.

[6] Prabhaputra, A. A. (2019). Sistem Outsourcing Dalam Hubungan Industrial Di Indonesia (Outsourcing System In Industrial Relation In Indonesia). 1 (1), 22-27.

[7] Rahim, R. A., Ahmad Tajuddin, M. A. bin, Abu Bakar, K. bin H., \& Abdul Rahim, M. N. Bin. (2015). Migrant Labour and Issues on Outsourcing System in Malaysia. SHS Web of Conferences, 18 , 01003 . https://doi.org/10.1051/shsconf/20151801003.

[8] Rohayati, D., \& Andreas, R. (2015). DENIAL OF LABOUR RIGHTS BY LIBERAL LEGAL REGIME IN THE OUTSOURCING SYSTEM. IMCOSS, 20-21.
[9] Simanjuntak, P. J. (2002). The New Law on Trade unions. 145 .

[10] Tayauova, G. (2012). Advantages and disadvantages of outsourcing: analysis of outsourcing practices of Kazakhstan banks. Procedia - Social and Behavioral Sciences, 41, 188195. https://doi.org/10.1016/j.sbspro.2012.04.023.

[11] Triyono. (2011). Outsourcing Dalam Perspektif Pekerja Dan Pengusaha. Ppk-Lipi, 6 (1). http://dspace.uii.ac.id.

[12] Xiaohua, L. (2008). An Empirical Study on Public Service Motivation and the Performance of Government Employee in China UNE ÉTUDE EMPIRIQUE SUR LA MOTIVATION DU SERVICE PUBLIQUE ET LA PERFORMANCE DES EMPLOYÉS DU GOUVERNEMENT EN CHINE. Canadian Social Science, 4 (2), 18. 